\title{
Far-infragravity and infragravity "pulses" in a rip current
}

\author{
B. Greenwood ${ }^{1}$, R. W. Brander ${ }^{2}$ \& E. Joseph ${ }^{2}$ \\ ${ }^{1}$ Department of Physical \& Environmental Sciences, \\ University of Toronto Scarborough, Canada \\ ${ }^{2}$ School of Biological, Earth \& Environmental Sciences, \\ University of New South Wales, Australia
}

\begin{abstract}
Rip currents are narrow, jet-like flows directed offshore through the breaker zone, often fed by shore-parallel feeder currents and forced by variable alongshore set-up induced by breaking gravity waves. Current speeds are not "quasi-steady", but "pulse" at a range of frequencies, some much lower than that of the incident waves. Relatively few field measurements identify these low frequency motions and even fewer record their sediment transport potential. Cross-shore velocities and sediment concentrations measured in a rip neck are used to: (a) identify the frequencies of these pulses and (b) assess the role of low frequencies in the transport of suspended sediment. Velocities at $\mathrm{z}=0.13$ and $0.39 \mathrm{~m}$ and concentrations at $\mathrm{z}=0.13,0.26$ and $0.39 \mathrm{~m}$ were recorded continuously at $4 \mathrm{~Hz}$ over several hours in a rip neck at Bennett's Beach, NSW, Australia. Spectral and cross-spectral analyses of $\sim 33$-minute records were used to identify low frequency modulations of the velocity and concentration fields, as well as the suspended sediment flux. A lack of spectral variance around $0.005 \mathrm{~Hz}$ marked the partition frequency between infragravity (IG) and far-infragravity (FIG) motions. At high tide when the mean cross-shore current at $\mathrm{z}=0.13 \mathrm{~m}$ was at its maximum $\left(\sim 0.38 \mathrm{~m} \mathrm{~s}^{-1}\right)$ : (a) the dominant frequency was a FIG pulse at $0.0026-0.0028 \mathrm{~Hz}$ ( $\sim 5-6$ minutes). (b) IG motions also occurred with a 0.0199 $\mathrm{Hz}(\sim 50 \mathrm{~s})$ pulse dominating. (c) near the bed, concentrations were strongly modulated at FIG frequencies, but at higher elevations, the spectra were distinctly "red". (d) co-spectra revealed an offshore sediment flux dominated by a FIG pulse centered at $0.00244 \mathrm{~Hz}$ ( 6-7 minutes). IG pulses between 0.0129
\end{abstract}


and $0.0132 \mathrm{~Hz}(76-78 \mathrm{~s})$ were less dominant, although both FIG and IG frequencies produced a net offshore transport of suspended sediment.

Keywords: rip currents, sediment concentrations, far-infragravity and infragravity pulses, sediment flux.

\section{Introduction}

On barred coasts, rip currents are narrow, topographically-constrained, "quasisteady" flows directed offshore through the breaker zone as "jet-like" flows reaching speeds up to $\sim 2 \mathrm{~m} \mathrm{~s}^{-1}$ and forced by variable alongshore set-up induced by incident gravity waves breaking on a segmented nearshore bar. It is clear from the literature, however, that rip currents are not remotely "quasi-steady"; they are modulated by "pulsations" at a range of frequencies, often much lower than those of the incident gravity waves. Frequently, "rips" form an integral part of a cellular water and sediment circulation in both marine and lacustrine surf zones; the classic circulation model is a net flux of water landward across the bar under the breaking waves followed by an alongshore and seaward flux through the feeder channel and rip neck respectively (Komar [1]). This flux is often modulated by the tide, even under micro-tidal conditions (Aagaard et al. [2]; Brander [3, 4]; MacMahan et al. [5, 6]; Bruneau et al. [7]). Since the early work of Shepard [8], Shepard et al. [9], McKenzie [10], Reimnitz [11], Reimnitz et al. [12], Cook [13] and Greenwood and Davidson-Arnott [14, 15] and more recently Smith and Largier [16] and Thornton et al. [17], the assumption has been that rips play an important role in maintaining both the water and sediment balance on the upper shoreface, and are a large constraint on topographic change. However, recent field and numerical experiments have seriously questioned this basic assumption, at least with respect to the flux of fluid (MacMahan et al. [18, 19]). It appears that many cellular flows in the nearshore involve closed vortical systems inside the breaker line and only occasionally do rip currents expel water offshore (MacMahan et al. [19]). These very low frequency "pulses" in the offshore flow would appear to be the main mechanism for water exchange between the surf zone and the rest of the upper shoreface. However, the nature of theses "pulses" and role they play in transporting sediment is virtually unknown, since measurements of sediment flux are extremely limited.

\section{Low frequency motions ("pulses") in rip systems}

Low frequency oscillations in nearshore wave and current systems have been documented for many years since the early work on "surf beat" by Munk [20] and Tucker [21]. More recently, Aagaard et al. [2] showed that infragravity oscillations were important to the net flux of suspended sediment in rip current systems at least at certain stages of the tide (low tide); furthermore, Greenwood et al. [22] demonstrated that infragravity oscillations do influence the net transport of suspended sediment at least in the rip neck under low to moderate energy conditions, and may in fact control the direction of the suspended sediment flux at certain stages of the tide. In this paper, we document very low 
frequency motions ("pulses") in a rip channel under swell conditions and demonstrate their potential to transport suspended sediment offshore.

\section{Location and nearshore bathymetry}

Bennett's Beach, NSW, Australia, is micro-tidal with a mixed semi-diurnal regime and was in an "intermediate" state (Wright and Short [23]) during the experiment. Samples from the medium sand beach were well-sorted, bimodal, with a mean grain size of $1.79 \varnothing(300 \mu \mathrm{m})$ and a standard deviation of $0.37 \varnothing$ $(91 \mu \mathrm{m})$. The beach was subject to long period swell from the SE during the experiment, coupled with a variable wind-wave field forced by a daily sea breeze cycle. Figure 1 illustrates the study rip cell on February $19^{\text {th }} 2004$ after injection of a tracer at the head of the feeder channel. The cell was asymmetric with a dominant feeder current from the southwest and a rip which broke through the bar in a narrow channel; beyond this neck the flow diffused to mix with water outside the surf zone. The bathymetry (Fig. 2) consisted of an oblique nearshore bar welded to a shoal to the south, extending alongshore in a north-easterly direction to end at the rip neck; a trough between the bar and the beach face, varied in depth from near zero where the bar was welded to the shoal, to $\sim 1 \mathrm{~m}$ before it turned offshore into the rip neck, which at high tide was $\sim 1.75 \mathrm{~m}$ deep. Over three-days, the bar migrated northeast and offshore, forcing the neck northward as it was constricted and deepened (Figs. 1 and 2).

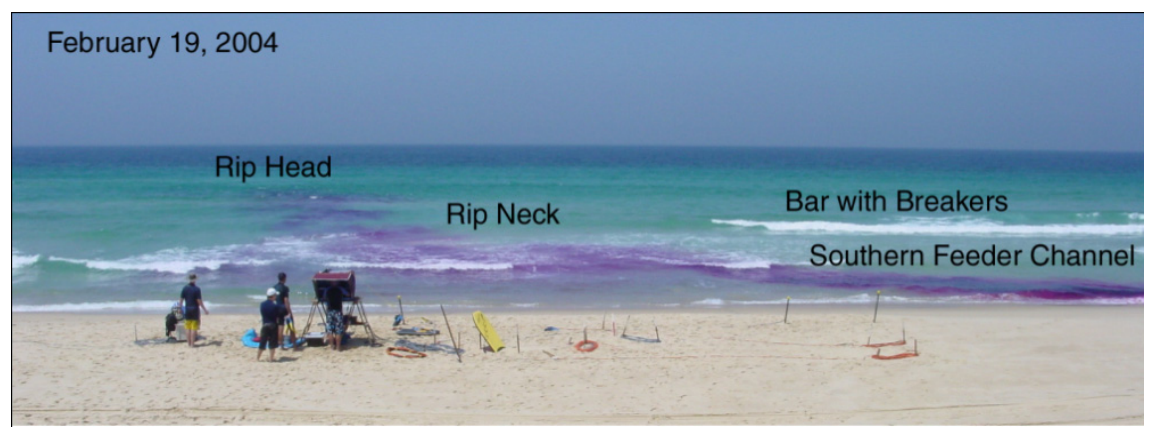

Figure 1: Tracer deployed in the rip cell at Bennett's Beach, NSW, Australia. Note the breaking waves on the segmented bar, the flow in the southern feeder channel, the narrow jet in the rip neck and the diffused rip head.

\section{Measurement and analytical techniques}

Instruments were deployed at high tide in the centre of the rip neck (P1, Fig. 2) to measure: (a) the cross-shore and alongshore (relative to the average local shoreline orientation) horizontal currents, at elevations of $\mathrm{z}=0.13,0.39$ and $0.50 \mathrm{~m}$, using biaxial electromagnetic current meters (Marsh-McBirney, OEM 512); (b) sediment concentrations at $\mathrm{z}=0.13,0.26,0.39 \mathrm{~m}$, using optical 


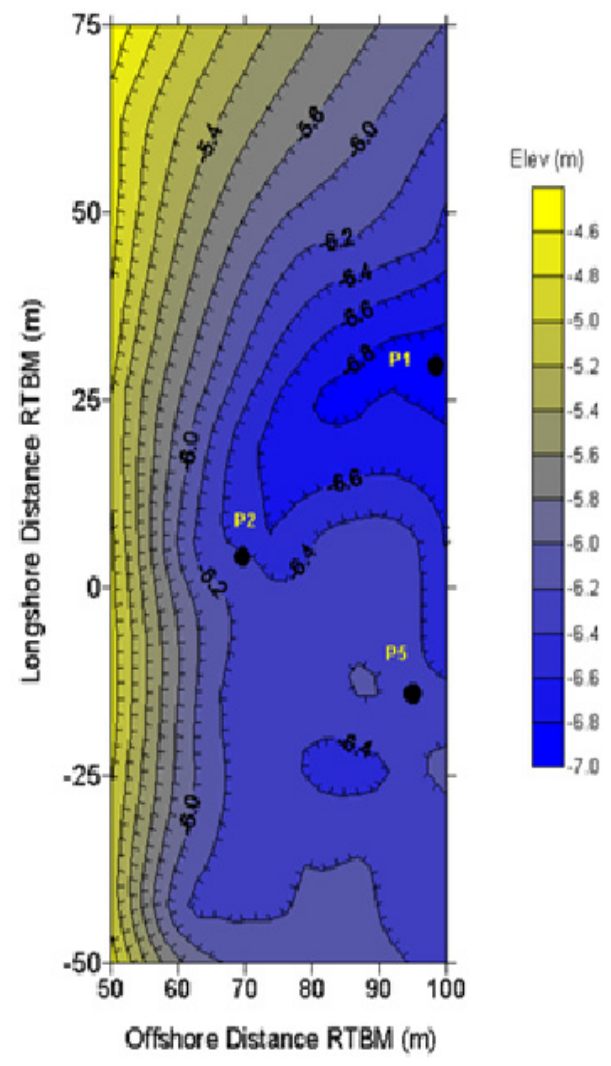

Figure 2: $\quad$ Nearshore bathymetry, Bennett's Beach, February $21^{\text {st }}$. P1 marks the location of the instrument pod in the rip neck and P2 and P5 marks the location of the pods in the feeder channel and on the bar crest, respectively. NB: RBTM is relative to the bench mark.

backscatter sensors (D\&A Instruments, OBS-1P and OBS-3); and (c) mean water surface elevation and waves, using a strain-gauge pressure sensor (Druck-1830). Waves incident to the surf zone were recorded by a Druck pressure sensor deployed $\sim 130 \mathrm{~m}$ directly offshore of the bar. For transport calculations, concentrations measured at 0.13 and $0.26 \mathrm{~m}$ were coupled with velocities measured at $0.13 \mathrm{~m}$; concentrations measured at $\mathrm{z}=0.39 \mathrm{~m}$ were coupled with velocities measured $\mathrm{z}=0.39 \mathrm{~m}$. There is the potential for error here (Austin and Masselink [24]); in all cases currents at $0.13 \mathrm{~m}$ were only very slightly different from those at 0.39 and $0.50 \mathrm{~m}$; the latter were essentially identical. The sensors were supported on a heavy solid based support pod, which did not allow significant shifts in elevation once the support settled. The currents and sediment transports were also averaged over significant time blocks, with continuous recording at $4 \mathrm{~Hz}$. Spectral analyses of "long" time series were used to identify frequency components beyond the range of incident gravity waves. This assumes 
that the recorded variables are "stationary"; a random variable or process is said to be stationary if its statistical parameters (e.g. mean, variance, etc.) are independent of time. In reality, only weakly stationary processes exist in nature; the assumption is that if the controlling variables in the system (e.g. incident waves, tidal level) are stable, then the underlying frequency structure of the resulting current and concentration time series can still be determined by appropriate demeaning and detrending. Blocks of 8000 points were demeaned and detrended, on the assumption that $\sim 33$ minutes is long enough to identify farinfragravity pulses, but short enough that the system remained quasi-stationary. Within this time frame, tidal changes did not exceed $0.11 \mathrm{~m}$ and the incident swell remained unchanged. Series of "collocated" velocities and concentrations were used to compute the time-averaged net, mean, and oscillatory components of the suspended sediment transport (SST) rate for a 2-dimensional, vertical section of fluid at each elevation (see Jaffe et al. [25]; Huntley and Hanes [26]; Osborne and Greenwood [27]):

$$
\begin{gathered}
<q_{s}>_{\text {net }}=\frac{1}{T} \int_{0}^{T} \int_{0}^{h} U_{(z, t)} C_{(z, t)} d z d t \\
<q_{s}>_{\text {mean }}=\frac{1}{T}\left[\int_{0}^{T} \int_{0}^{h} U_{(z, t)}\right] * \frac{1}{T}\left[\int_{0}^{T} \int_{0}^{h} C_{(z, t)}\right] \\
<q_{s}>_{o s c}=\frac{\Delta f}{f_{c}} \int_{0}^{T} \int_{0}^{h} C_{(U C)}(f)
\end{gathered}
$$

where $\mathrm{U}_{(\mathrm{z}, \mathrm{t})}=$ horizontal water velocity $\left(\mathrm{m} \mathrm{s}^{-1}\right)$, which can be disaggregated into cross-shore and alongshore components; $\mathrm{C}_{(\mathrm{z}, \mathrm{t})}=$ sediment concentration $\left(\mathrm{kg} \mathrm{m}^{-3}\right)$; $\mathrm{z}=$ height above the bed $(\mathrm{m}) ; \mathrm{t}=$ time $(\mathrm{s}) ; \mathrm{h}=$ water depth $(\mathrm{m}) ; \mathrm{T}=$ time of integration $(\mathrm{s}) ;<>=$ time-averaged term; $\mathrm{C}_{(\mathrm{UC})}=$ co-spectrum of the horizontal velocities and concentrations; $f=$ frequency band of the oscillation $(\mathrm{Hz}) ; \Delta \mathrm{f}=$ bandwidth for spectral estimates; $f_{c}=$ frequency range. The co-spectrum identifies SST due to oscillatory motions, which can be partitioned into different frequency ranges (Huntley and Hanes [26]; Davidson et al. [28]). Gravity and infragravity waves were partitioned at $0.04 \mathrm{~Hz}(25 \mathrm{~s})$ and infragravity and far infragravity frequencies at $0.005 \mathrm{~Hz}(200 \mathrm{~s})$, at pronounced reductions in spectral variance.

\section{Results: February $21^{\text {st }}, 2004$}

Measurements when the rip was at a maximum will be used to demonstrate the presence of very low frequency velocity "pulses" and their potential to suspend and transport sediment. Examination of $\sim 1.5 \mathrm{~h}$ of record from the rip neck (P1; Fig. 2) of the near-bed, cross-shore velocity and suspended sediment concentration (Fig. 3) reveals that both signals are modulated at frequencies lower than the incident waves. Although the mean cross-shore current was $\sim 0.38$ $\mathrm{m} \mathrm{s}^{-1}($ at $\mathrm{z}=0.13 \mathrm{~m})$ and directed offshore, the current fluctuated from $>1.64 \mathrm{~m} \mathrm{~s}^{-1}$ offshore to almost $-1.44 \mathrm{~m} \mathrm{~s}^{-1}$ onshore. Sediment concentrations revealed low frequency "pulses", ranging from $<<2 \mathrm{~kg} \mathrm{~m}^{-3}$ to $>30 \mathrm{~kg} \mathrm{~m}^{-3}$ (Fig. 3). 

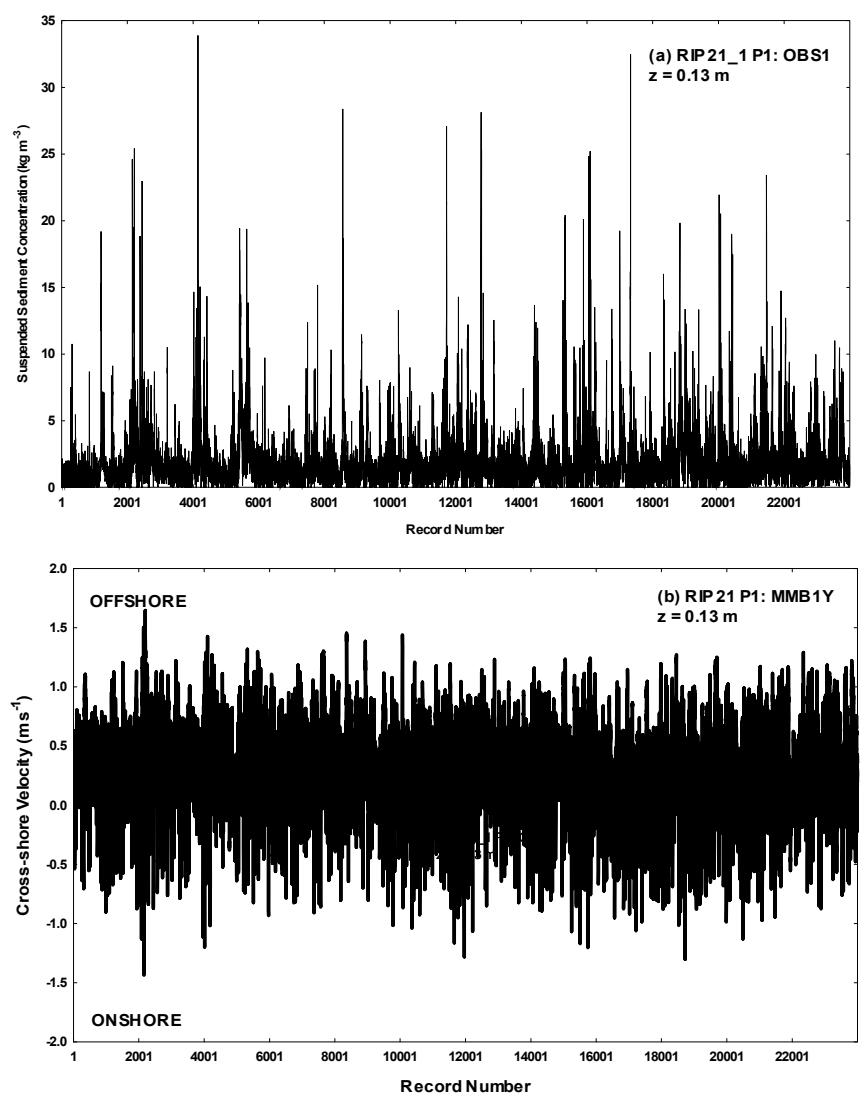

Figure 3: Time series of $\sim 1.67 \mathrm{~h}$ of near-bed suspended sediment concentrations (a) and cross-shore rip current velocities (b), measured at $\mathrm{z}=0.13 \mathrm{~m}$ elevation and recorded at $4 \mathrm{~Hz}$ in the rip neck at high tide. Note the distinct low frequency modulation of the signals.

\subsection{Far-infragravity and infragravity pulses in the rip current}

Figure 4 illustrates frequency spectra of the cross-shore currents measured at P1 (Fig. 2) at elevations of $\mathrm{z}=0.13$ and $0.26 \mathrm{~m}$ for $\sim 33$ minutes at high tide $(1350 \mathrm{~h}$, Feb. $\left.21^{\text {st }}\right)$, when the rip velocity was at a maximum $\left(\sim 0.38 \mathrm{~m} \mathrm{~s}^{-1}\right.$; see Greenwood et al. [22]). The time series were first tested for their difference from "white noise" using the Bartlett-Kolmogorov Smirnov distance statistic, $d$ (Fuller [29]). For the $\sim 8000$-point series, the computed $d$-statistics were 0.775 for currents at $\mathrm{z}$ $=0.13 \mathrm{~m}$ and 0.786 for currents at $\mathrm{z}=0.26 \mathrm{~m}$. Clearly, the series were significantly different from white noise $(\alpha<0.01)$, and spectral densities were concentrated at both far-infragravity (FIG) and infragravity (IG) frequencies. These low frequency motions dominated the signal at this time scale. There were 

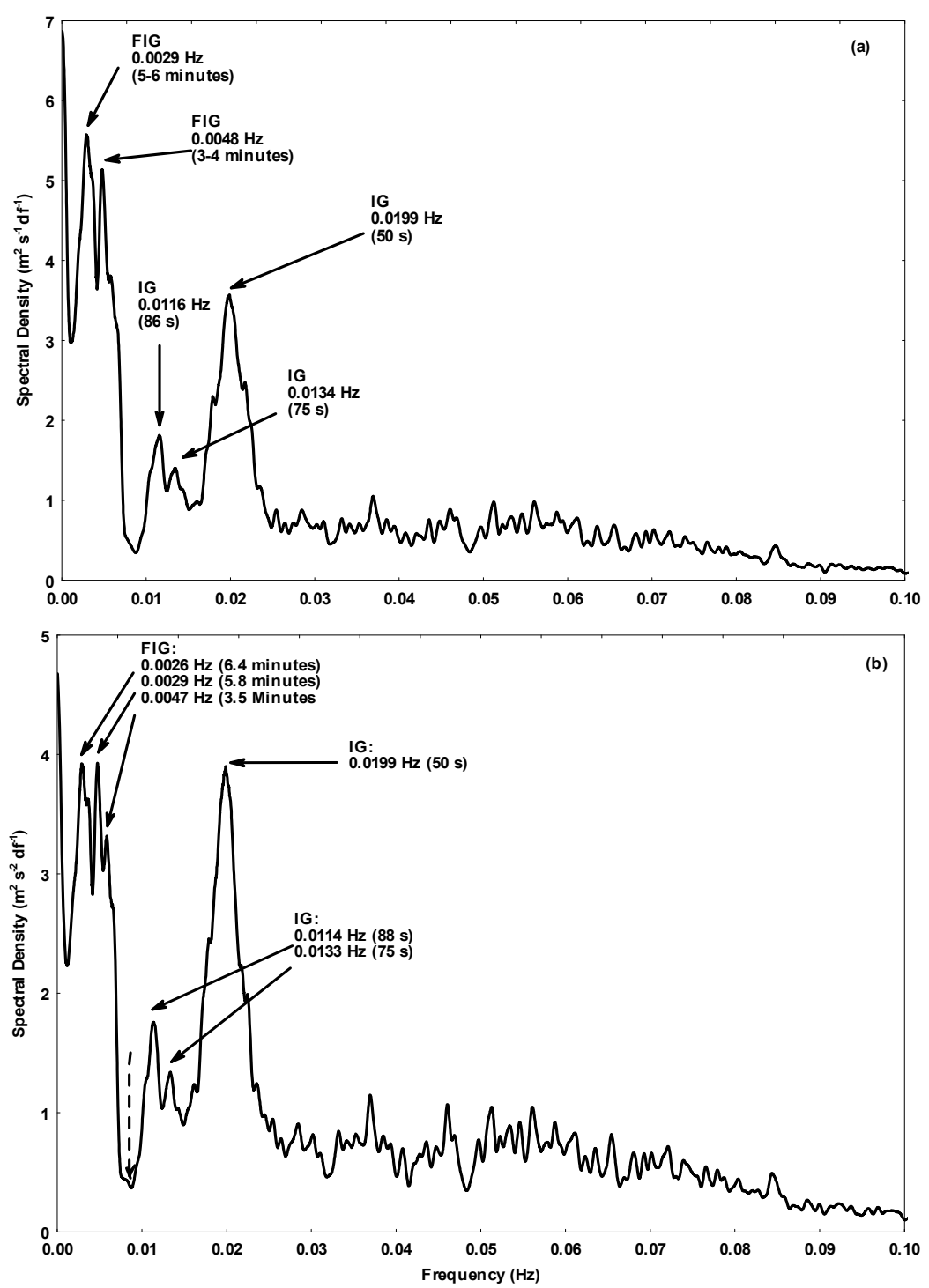

Figure 4: Frequency spectra of $\sim 33$ minutes of horizontal cross-shore currents in the rip neck at high tide at two elevations: (a) $\mathrm{z}=0.26$ $\mathrm{m}$; (b) $\mathrm{z}=0.13 \mathrm{~m}$. The dashed vertical arrow in (b) represents the partition frequency between far-infragravity (FIG) and infragravity (IG) frequencies.

no significant spectral density peaks at either the incident swell frequency $(0.077-0.083 \mathrm{~Hz} ; 12-13 \mathrm{~s})$ or that of the wind waves $(0.160-0.125 \mathrm{~Hz} ; 6-8 \mathrm{~s})$. FIG spectral peaks occurred at: (i) $0.0026-0.0029 \mathrm{~Hz}$ ( $\sim 5-6$ minutes); and (ii) $0.0048 \mathrm{~Hz}$ (3-4 minutes). The largest IG peak was at $0.0199 \mathrm{~Hz}(\sim 50 \mathrm{~s})$ 
almost as large as the FIG peak at $\mathrm{z}=0.13 \mathrm{~m}$; subsidiary IG peaks occurred at $0.0114-0.116 \mathrm{~Hz}(86-88 \mathrm{~s})$ and $0.0133-0.0134 \mathrm{~Hz}(\sim 75-76 \mathrm{~s})$. Not all these low frequency motions were reflected in the concentration spectra. Nevertheless, the Bartlett-Kolmogorov $d$-statistic showed that all three concentration series also differed significantly from "white noise". The $d$-statistic values were 0.586 , 0.562 and 0.458 respectively for the spectra at $0.13,0.26$ and $0.39 \mathrm{~m}$. At $\mathrm{z}=$ $0.13 \mathrm{~m}$, a large FIG peak at $0.0028 \mathrm{~Hz}$ ( $\sim 6$ minutes; Fig. 5a), matched the largest peak in the cross-shore current spectrum (Fig. 4), suggesting a direct causal link. A smaller but much less distinct peak at the same frequency was also evident in the concentrations at $\mathrm{z}=0.26 \mathrm{~m}$. However, no other FIG peaks were revealed in the concentration spectra and instead the spectra were distinctly "red", and increasingly so with increased elevation. There were small peaks in concentration at IG frequencies $(0.0124$ and $0.0203 \mathrm{~Hz} ; 80$ and $50 \mathrm{~s})$, which matched similar frequencies in the current velocities (e.g 0.0133 and $0.0198 \mathrm{~Hz}$; Fig. 4). At the highest elevation $(\mathrm{z}=0.39 \mathrm{~m})$, there was some evidence for a spectral peak at $0.0198 \mathrm{~Hz}(\sim 50 \mathrm{~s})$, although the most prominent signature was that of the swell frequency $(0.0889 \mathrm{~Hz} ; 11-12 \mathrm{~s})$. Examination of shorter time series ( $\sim 17$ minutes) at the beginnning of these long records revealed that the incident swell ( $\sim 12-13 \mathrm{~s})$ was the dominant spectral signature at this shorter time scale, with a smaller contribution from locally generated wind waves (Greenwood et al. [22]). Thus, it appears that near the bed, sediment concentrations do respond to the lower frequency water motions (FIG, IG frequencies); this linkage decreases with elevation, where the dominant incident swell, ( 0.08-0.09 Hz; 11-12 s) increases in importance.

\subsection{Suspended sediment flux at low frequencies}

Figure 6 illustrates the co-spectra computed using the cross-shore current at $\mathrm{z}=$ $0.13 \mathrm{~m}$ and sediment concentrations recorded at $\mathrm{z}=0.13$ and $0.26 \mathrm{~m}$ in the rip neck for $\sim 33$ minutes at high tide. Within this time frame, the suspended sediment transported by the incident swell and wind waves is subordinate to that of the lower frequency motions. Transport of suspended load at FIG frequencies peaked at $0.00244 \mathrm{~Hz}(\sim 6-7$ minutes $)$, with the flux directed offshore at both $\mathrm{z}=$ 0.13 and $0.26 \mathrm{~m}$ ), supporting the transport by the mean rip current itself (Greenwood et al. [22]). IG transports varied in both magnitude and direction but with a net transport offshore as well over this time period. The incident wave frequencies, as expected, induced a net onshore transport of suspended sediment.

\section{Conclusions}

At relatively large time scales ( $\sim 33$ minutes), cross-shore current and sediment concentration measurements in a "stable" rip neck system at high tide when the rip was at a maximum $\left(\sim 0.38 \mathrm{~m} \mathrm{~s}^{-1}\right)$ lead to the following conclusions: 

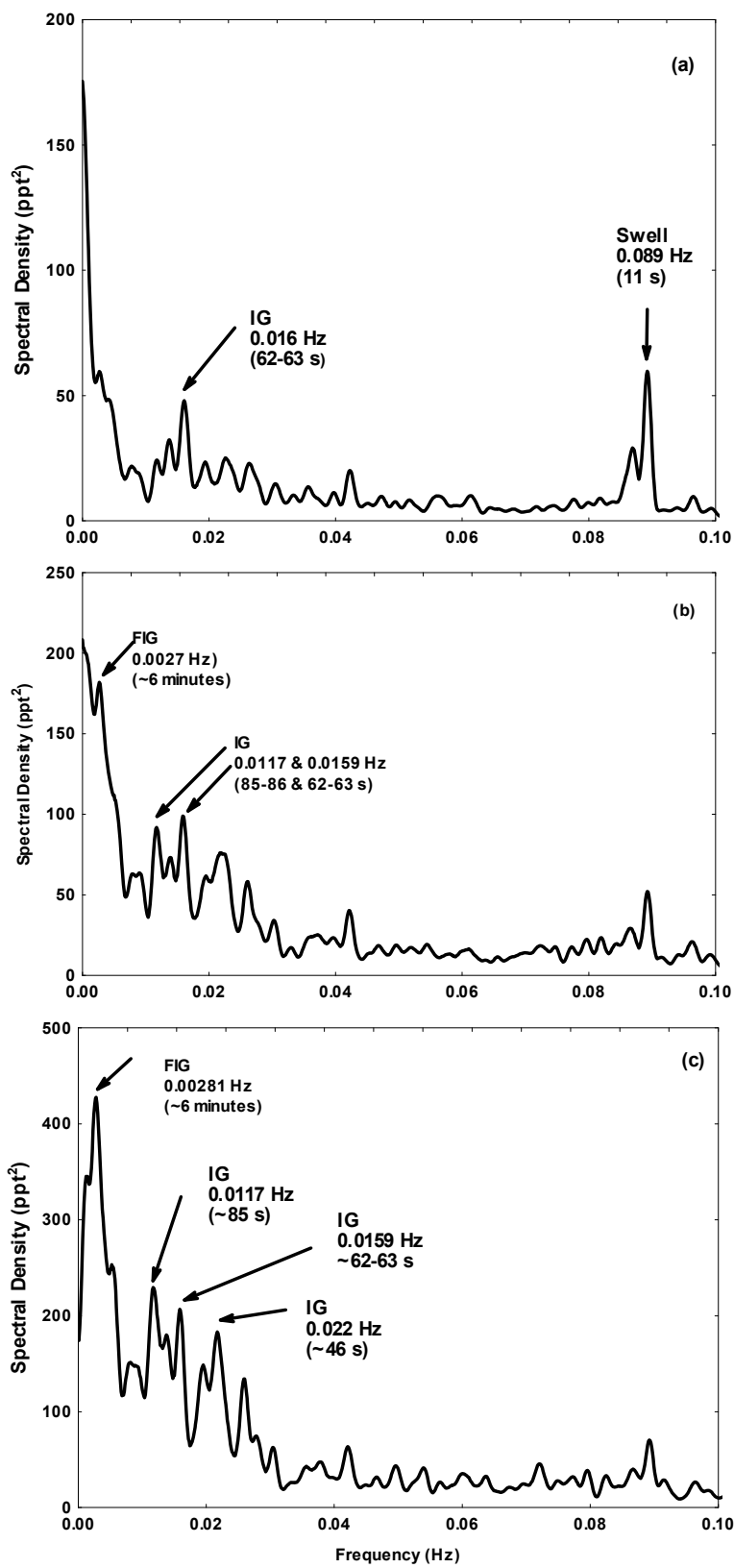

Figure 5: Frequency spectra of $\sim 33$ minutes of near-bed, sediment concentrations in the rip neck at high tide: (a) $\mathrm{z}=0.39 \mathrm{~m}$; (b) $\mathrm{z}=$ $0.26 \mathrm{~m}$; (c) $\mathrm{z}=0.13 \mathrm{~m}$. Note the decreasing vertical scale with elevation as overall concentrations decrease. 

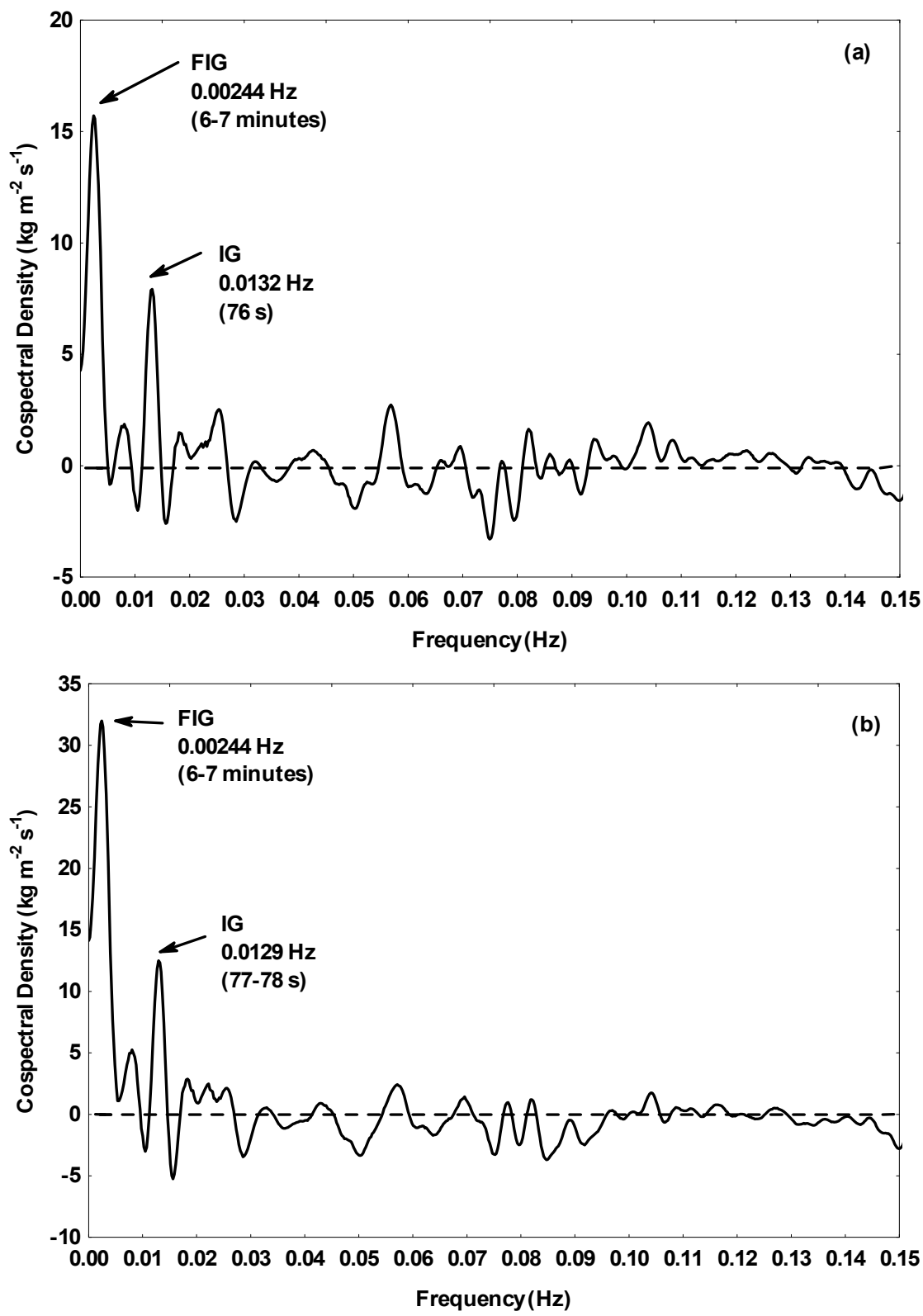

Figure 6: Co-spectra of cross-shore velocity and sediment concentration at $\mathrm{z}$ $=0.26 \mathrm{~m}$ (a) and $0.13 \mathrm{~m}$ (b) in the rip neck recorded over $\sim 33$ minutes. Note the difference in the vertical scales, which reflects the decreasing concentration with elevation, as there is essentially no change in the velocity field. 
- current pulses at far-infragravity frequencies $(>0.005 \mathrm{~Hz} ;>200 \mathrm{~s})$ dominate the near-bed cross-shore velocity spectrum $(\mathrm{z}=0.13,0.39 \mathrm{~m})$. The dominant farinfragravity frequency was $0.0026-0.0028 \mathrm{~Hz}$ ( $\sim 5-6$ minutes).Further low frequency motions occurred at infragravity frequencies, with a dominant "pulse" at $0.0199 \mathrm{~Hz}(\sim 50 \mathrm{~s})$.

- similar very low frequency "pulses" were found in the near-bed $(\mathrm{z}=0.13,0.26$ $\mathrm{m})$ sediment concentration field. The strength of the signal decreased rapidly with elevation, so that at $0.39 \mathrm{~m}$, the spectrum was distinctly "red" with no preferred concentration of variance at any FIG frequency. Instead, the only clear signal was that of an IG "pulse" at $0.0199 \mathrm{~Hz}(\sim 50 \mathrm{~s})$.

- co-spectra between currents and concentrations revealed that suspension transport was also dominated by FIG "pulses", at frequencies between 0.0026 and $0.0047 \mathrm{~Hz}$ (3.5 and 6.5 minutes), inducing a net offshore flux of sediment. IG frequencies were also present with the largest "pulse" $(0.0129-0.0132 \mathrm{~Hz}$; 76-78 s) also transporting suspended sediment offshore.

- at shorter time scales ( $\sim 17$ minutes) both the spectra and co-spectra were dominated by the incident swell $(0.082 \mathrm{~Hz} ; \sim 12 \mathrm{~s})$ and wind waves generated by a sea breeze $(0.167 \mathrm{~Hz} ; 6 \mathrm{~s})$; these higher frequency waves together with the mean current were the dominant transport at short time scales (Greenwood et al. [22]).

Neither the consistency of the low frequency pulses through time, nor their origin(s), can be discussed in detail here, although a number of possible forcing mechanisms should be mentioned: (a) inherent modulations of the landward mass transport by Stokes drift or wave rollers over the segmented bar (Aagaard et al. [2]), which is the fundamental driver of the rip cell; (b) standing farinfragravity and infragravity waves within the rip neck itself produced by wave grouping (MacMahan et al. [6]; Bruneau et al. [7]); and (c) current shear instabilities (Smith and Largier [16]) and (d) the expulsion of vortices from the surf zone induced by wave-group forcing of large scale Lagrangian structures (MacMahan et al. [19]; Reniers et al. [30, 32]).

\section{Acknowledgements}

NSERC Canada (BG) and an FRGP grant from the UNSW (RWB) provided funding; M. Daly, M. Hughes, T. Baldock \& F. Weir helped in the field. Dave Mitchell (Sydney University) is thanked for his technical and culinary skills.

\section{References}

[1] Komar, P.D. Beach Processes and Sedimentation. 2nd Edition, Prentice Hall, New Jersey, p. 338, 1998.

[2] Aagaard, T., Greenwood, B., Nielsen, J. Mean currents and sediment transport in a rip channel. Marine Geol., 140: 25-45, 1997.

[3] Brander, R.W. Field observations on the morphodynamic evolution of lowenergy rip systems. Marine Geol., 157: 199-217, 1999. 
[4] Brander, R.W. Morphodynamics of a large-scale rip current system at Muriwai Beach, New Zealand. Marine Geol., 165: 27-39, 2000.

[5] MacMahan, J.H., Thornton, E.B., Stanton, T.P., Reniers, A.J.H.M. RIPEX: observations of a rip current system. Marine Geol., 218: 113-134, 2005.

[6] MacMahan, J.H., Thornton, E.B., Reniers, A.J.H.M. Rip Current Review. Coastal Eng., 53: 191-208, 2006.

[7] Bruneau, N., Castelle, B., Bonneton, P., Pedreros, R. Very low frequency motions of a rip current system: observations and modeling. Journal of Coastal Research, SI 56: 1731-1735, 2009.

[8] Shepard, F.P. Undertow, rip-tide or "rip current". Science, New Series, 84: 181-182.

[9] Shepard, F.P., Emery, K.O. LaFond, E.C. Rip currents: a process of geological importance. Journal Geology, 49: 337-369, 1941.

[10] McKenzie, P. Rip-current systems. Journal Geology, 66: 103-113.

[11] Reimnitz, E. Surf-beat origin for pulsating bottom currents in the Rio Balsas submarine canyon. Geol. Soc. Am. Bull. 82: 81-90, 1975.

[12] Reimintz, E., Toimil, L.J, Shepard, F.P., Gutierrez-Estrana, M. Possible rip current origin for bottom ripple zones to $30 \mathrm{~m}$ depth. Geology 4: 395-400, 1976.

[13] Cook, D.O., The occurrence and geologic work of rip currents off southern California. Marine Geology, 9: 173-186, 1970.

[14] Greenwood, B., Davidson-Arnott, R.G.D. Marine bars and nearshore sedimentary processes, Kouchibouguac Bay, New Brunswick. In: Nearshore Sediment Dynamics and Sedimentation, edited by Hails, J. and Carr, A., John Wiley and Sons, London, p.123-150, 1975.

[15] Greenwood, B, Davidson-Arnott, R.G.D. Sedimentation and equilibrium in wave-formed bars: a review and case study. Canadian J. Earth Sciences, 16: 312-332, 1979.

[16] Smith and Largier, Observations of nearshore circulation: rip currents. Journal Geophyical Res., 100: 10967-10975.

[17] Thornton, E.B., MacMahan, J., Sallenger Jr., A.H., Rip currents, megacusps, and eroding dunes, Marine Geology 240: 151-167, 2007.

[18] MacMahan, J.H., Reniers, Ad J.H.M., Thornton, E.B. and Stanton, T.P. Infragravity rip current pulsations. Journal Geophysical Res., 109: C01033, 2004.

[19] MacMahan, J.H., Brown, J., Brown Jenna, Thornton, E.B. Reniers, Ad, Stanton, T., Henriquez, M., Gallagher, E., Morrison, J., Austin, M.J., Scott, T.M., Senechal, N. Mean Lagrangian flow behavior on an open coast ripchanneled beach: a new perspective. Marine Geol., 268: 1-15, 2010.

[20] Munk, W. H. Surf beats. EOS Trans. Amer. Geophyical. Union, 30: 849854, 1949.

[21] Tucker, M. J. Surf beats: sea waves of 1 to 5 minutes period. Proc. Royal Soc. (A) 202: 565-573, 1950. 
[22] Greenwood, B., Brander, R.W., Joseph, R., Hughes, M.G., Baldock, T. and Aagaard, T., 2009. Sediment flux in a rip channel on a barred intermediate beach under low wave energy. In: Coastal Processes, edited by C.A. Brebbia, G. Benassai \& G.R. Rodriguez, WIT Press, p.197-209.

[23] Wright, L.D., Short, A.D. Morphodynamic variability of surf zones and beaches: a synthesis. Marine Geol., 56: 93-118, 1984.

[24] Austin, M.J., Masselink, G. The effect of bedform dynamics on computing suspended sediment fluxes using optical backscatter sensors and current meters. Coastal Eng. 55: 251-260, 2008.

[25] Jaffe, B.E., Sternberg, R.W., Sallenger, A.H. The role of suspended sediment in shore-normal beach profile changes. Proceedings of the $21^{\text {st }}$ Coastal Engineering Conference, American Society Civil Engineers, p. 1725-1743, 1984.

[26] Huntley, D.A., Hanes, D.M. Direct measurement of suspended sediment transport. Proceedings of Coastal Sediments '87, ASCE, New York, p. 723737, 1987.

[27] Osborne, P.D., Greenwood, B. Frequency dependent cross-shore suspended sediment transport 1: a non-barred shoreface, Queensland Beach, Nova Scotia, Canada. Marine Geol., 106: 1-24, 1992.

[28] Davidson, M.A., Russell, P.E., Huntley, D.A., Hardisty, J. Tidal asymmetry on a macro-tidal intermediate beach. Marine Geol., 110: 333-353, 1993.

[29] Fuller, W.A. Introduction to Statistical Time Series. Wiley, New York.

[30] Reniers, Ad. J. H. M., MacMahan, J. H., Thornton, E. B., Stanton, T. P., Henriquez, M., Brown, J. W., Brown, J. A., Gallagher, E. Surf zone surface retention on a rip-channeled beach. Journal Geophysical Res., 114, C10010, doi:10.1029/2008JC005153, 2009.

[31] Reniers, A. J. H. M., MacMahan, J. H., Beron-Vera, F. J., Olascoaga, M. J. Rip-current pulses tied to Lagrangian coherent structures. Geophysical Res. Lett., 37, L05605, 5 p., 2010. 